\title{
The Rat Hepatocyte Plasma Membrane Organic Anion Binding Protein Is Immunologically Related to the Mitochondrial $F_{1}$ Adenosine Triphosphatase $\beta$-Subunit
}

\author{
Tobias Goeser," Ryo Nakata, " Lawrence F. Braly," Alexander Sosiak, ${ }^{*}$ Celeste G. Campbell," Rolf Dermietzel," \\ Phyllis M. Novikoff, ${ }^{5}$ Richard J. Stockert, "\|l Robert D. Burk, " \\ Liver Research Center, Departments of Medicine, * Pathology, ${ }^{8}$ Biochemistry," Pediatrics, ${ }^{7}$ Microbiology and Immunology, ** \\ and Obstetrics and Gynecology, ${ }^{\ddagger \ddagger}$ Albert Einstein College of Medicine, Bronx, New York 10461; and \\ ${ }^{\ddagger}$ Anatomical Institute, University of Regensburg, Regensburg, Federal Republic of Germany D-8400
}

\begin{abstract}
A 55-kD organic anion binding protein (OABP) was identified previously in liver cell plasma membrane sinusoidal subfractions. Although this protein was localized to the surface of hepatocytes by immunofluorescence, immunoblot analysis revealed reactivity toward both plasma membrane and mitochondrial fractions. To clarify these findings, an immunoreactive clone from a rat liver cDNA expression library was isolated, the 1,500-base pair cDNA insert was sequenced, and the corresponding $\beta$-galactosidase fusion protein was expressed and purified. The resulting sequence corresponded to that of the rat mitochondrial $F_{1}$-adenosine triphosphatase $\left(F_{1}-A T P\right.$ ase) $\beta$-subunit. This protein and OABP are of similar size and are mutually immunologically cross-reactive. That the antigen was present on the cell surface as well as in mitochondria was suggested from studies of immunoprecipitation after cell-surface iodination, and light- and electron-microscopic immunocytochemistry. Photoaffinity labeling of bovine $F_{1}-A T P a s e$ with high-specific-activity $\left[^{35}\right.$ S]sulfobromophthalein revealed binding only to the $\beta$-subunit. Hepatocyte uptake of bilirubin and sulfobromophthalein requires cellular ATP and mitochondria also transport these organic anions, which at high doses inhibit respiration. The presence of an organic anion binding site on the $F_{1}$-ATPase $\beta$-subunit suggests that it may play a role in these processes. (J. Clin. Invest. 1990. 86:220-227.) Key words: bilirubin $\bullet$ liver $\bullet$ photolabeling $\bullet$ sulfobromophthalein • transport
\end{abstract}

\section{Introduction}

The organic anions bilirubin and sulfobromophthalein (BSP) ${ }^{1}$ circulate tightly bound to albumin $(1,2)$. The avidity of albumin for these compounds is such that, at equimolar concentrations, $<0.1 \%$ of ligand remains unbound at equilibrium (3). Despite the fact that these organic anions are protein bound,

Address reprint requests to Dr. Allan Wolkoff, Liver Research Center, Albert Einstein College of Medicine, 1300 Morris Park Avenue, Bronx, NY 10461.

Received for publication 20 November 1989 and in revised form 21 February 1990.

1. Abbreviations used in this paper: $\mathrm{BSP}$, sulfobromophthalein; OABP, organic anion binding protein.

J. Clin. Invest.

(C) The American Society for Clinical Investigation, Inc.

0021-9738/90/07/0220/08 \$2.00

Volume 86, July 1990, 220-227 they are rapidly extracted from their protein carrier by the liver (2). Previous studies revealed that hepatocyte uptake of bilirubin and BSP had carrier-mediated kinetics $(1,4)$. In particular, recent studies performed in short-term cultured rat hepatocytes revealed that this uptake process was saturable, temperature sensitive, inhibited after depletion of cellular ATP, and dependent upon the presence of $\mathrm{Cl}^{-}$in medium $(5,6)$.

We identified a 55-kD protein in sinusoidal surface-derived subfractions of liver cell plasma membrane as a putative organic anion transporter that bound photoactivated $\left[{ }^{35} \mathrm{~S}\right] \mathrm{BSP}$ (7). Subsequently, we purified this organic anion binding protein (OABP) from deoxycholate-solubilized rat liver cell plasma membrane by using BSP-Sepharose affinity chromatography (7). Through the use of monospecific antibody, OABP was localized to the surface of hepatocytes by immunofluorescence (8). However, immunoblot analysis revealed reactivity towards both plasma membrane and mitochondrial fractions (8). To clarify these findings, we have screened a rat liver cDNA expression library with this antibody. DNA inserts of isolated clones were sequenced and expressed as $\beta$-galactosidase fusion proteins. The cDNA sequence was identical to the sequence of the $3^{\prime} 1,500$ base pairs of the $\beta$-subunit of rat mitochondrial $F_{1}$-adenosine triphosphatase ( $\left.F_{1}-A T P a s e\right)$. These proteins are of similar size and are mutually immunologically cross-reactive. We present data suggesting that this antigen resides on both the plasma membrane and the inner mitochondrial membrane of the hepatocyte.

\section{Methods}

Rat liver cDNA library screening. A rat liver $\lambda g t 11 \mathrm{cDNA}$ expression library (Clontech Laboratories, Inc., Palo Alto, CA) was screened for OABP expression by the method of Young and Davis (9). In brief, goat anti-rat OABP antiserum, diluted $1: 100$ in $50 \mathrm{mM}$ Tris, $\mathrm{pH} 7.8,15$ $\mathrm{mM} \mathrm{NaCl}$ containing $3 \%(\mathrm{wt} / \mathrm{vol})$ bovine serum albumin (BSA) was used to identify OABP-expressing recombinants. Nitrocellulose filters were washed and blocked with $3 \%(\mathrm{wt} / \mathrm{vol}) \mathrm{BSA}$ and $0.3 \%(\mathrm{wt} / \mathrm{vol})$ dry milk in Tris-buffered saline at $4^{\circ} \mathrm{C}$. Positive plaques were visualized using rabbit anti-goat IgG horseradish peroxidase conjugate (Sigma Chemical Co., St. Louis, MO) (1:400) followed by incubation with 4-chloro-1-napthol peroxidase substrate solution (Kirkegaard \& Perry Laboratories, Inc., Gaithersburg, MD) according to the manufacturer's directions. Positive plaques were recovered and purified by rescreening at lower phage density.

Analysis of clones. Positive plaques were liquid amplified and phage DNA was purified. Insert size was determined after EcoRI digestion and agarose gel electrophoresis. Recombinant DNA was digested with $E c o$ RI, and the cDNA insert was gel purified and subcloned into the EcoRI site of pGEM2 plasmid (Promega Biotech, Madison, WI) for restriction analyses and sequencing.

Restriction endonuclease digestions were performed with $\mathrm{Bam} \mathrm{Hl}$, $B g l$ II, EcoRI, EcoRV, Hind III, Kpm I, Pst I, Pvu II, and Sph I 
(Boehringer Mannheim Diagnostics, Inc., Houston, TX) according to the manufacturer's instructions. For sequence determination, restriction fragments of the OABP cDNA were subcloned into pGEM $3 Z$. The DNA sequence was determined from double-stranded DNA using SP6 and T7 primers by the dideoxy chain termination procedure using $\left[{ }^{32}\right.$ P $]$ dATP or $\left[{ }^{35}\right.$ S $]$ dATP (Amersham Corp., Arlington Heights, IL) and a DNA sequencing kit (Promega Biotec).

Preparation of recombinant fusion protein in lysogenic bacteria. Escherichia coli strain Y1089, infected with the recombinant encoding the protein recognized by goat anti-rat OABP antiserum, was grown overnight in lysogenic bacteria media supplemented with $10 \mathrm{mM}$ $\mathrm{CaCl}_{2}$ at $32^{\circ} \mathrm{C}$. Aliquots of the culture, sufficient to yield 1,000 colonies per dish, were streaked on $150-\mathrm{mm}$ agar plates. Randomly selected colonies were incubated overnight at $32^{\circ} \mathrm{C}$ or $42^{\circ} \mathrm{C}$. Colonies that grew at $32^{\circ} \mathrm{C}$ but not at $42^{\circ} \mathrm{C}$ were presumed to be lysogenic.

Lysogenic colonies were grown in Luria-Bertani media at $32^{\circ} \mathrm{C}$ until $\mathrm{OD}_{260}$ was 0.6 . Incubation was continued for $20 \mathrm{~min}$ at $42^{\circ} \mathrm{C}$. Isopropyl $\beta$-D-thiogalactopyranoside was added to a final concentration of $4.2 \mu \mathrm{M}$ and incubation was continued for $1 \mathrm{~h}$ at $37^{\circ} \mathrm{C}$. Bacteria were harvested by centrifugation at $4,000 \mathrm{~g}$ for $5 \mathrm{~min}$ in a rotor (mode GSA, DuPont-Sorvall, Newtown, CT). The pellet was resuspended in $20 \mathrm{mM}$ sodium phosphate, $\mathrm{pH} 7.4$, then frozen in liquid nitrogen thawed, sonicated (model W140 Sonifier cell disrupter, Heat SystemsUltrasonics, Inc., Plainview, NY), and refrozen until used.

To purify the recombinant protein, the thawed pellet was then washed with $2 \mathrm{ml}$ of $1 \%$ Triton X-100 (Sigma Chemical Co.) in $0.02 \mathrm{M}$ sodium phosphate buffer ( $\mathrm{pH} 7.4$ ) followed by $2 \mathrm{ml}$ of $1 \%$ sodium deoxycholate (United States Biochemical Corp., Cleveland, $\mathrm{OH}$ ) in 0.2 $\mathrm{M}$ sodium phosphate (pH 7.4). The pellets were resuspended in $10 \%$ glycerol, $5 \%$ mercaptoethanol, 2.3\% SDS, $0.0625 \mathrm{M}$ Tris (pH 6.8) (sample buffer), and subjected to $7.5 \%$ SDS-PAGE. The recombinant fusion protein band at $160 \mathrm{kD}$ was excised and electroeluted from the gel (10).

Antibody studies. A female New Zealand rabbit (Hazleton Research Products, Inc., Denver, PA) was injected subcutaneously, at 1-mo intervals, with 6-40 $\mu \mathrm{g}$ of electroeluted fusion protein (8). To determine loss of antibody activity after absorption with OABP or fusion protein, $10 \mathrm{ml}$ of 1:1000 dilution of rabbit anti-rat OABP serum or anti-fusion protein serum in $5 \% \mathrm{BSA}, 50 \mathrm{mM}$ Tris, $0.15 \mathrm{M} \mathrm{NaCl}$, pH 7.6, was absorbed at $4^{\circ} \mathrm{C}$ overnight with $\sim 5-10 \mu \mathrm{g}$ of purified OABP or fusion protein. Residual antibody activity was assessed by immunoblot analysis (8).

Northern blot analysis. Rat liver total, poly $\mathrm{A}(+)$, and poly $\mathrm{A}(-)$ mRNA was prepared, electrophoresed on $1 \%$ agarose, and transferred to Gene Screen (New England Nuclear, Boston, MA) (11). Northern blot analysis was performed after ${ }^{32} \mathrm{P}$ labeling of the 1,250-base pair cDNA insert by primer extension using $\left[{ }^{32} \mathrm{P}\right] \mathrm{dCTP}$ (Amersham Corp.) (11).

Culture of isolated rat hepatocytes. Rat hepatocytes were isolated and cultured in monolayer at densities of $1.8 \times 10^{6} / 60-\mathrm{mm}$ dish in modified Waymouth's $752 / 1$ medium containing $5 \%$ fetal bovine serum $(6,12)$. The medium was changed $2 \mathrm{~h}$ after plating and cultures were used for studies $16 \mathrm{~h}$ after plating.

Surface iodination of short-term cultured rat hepatocytes. Cultured cells were washed twice with ice-cold $20 \mathrm{mM}$ PBS, $\mathrm{pH} 7.4$, and incubated in $1 \mathrm{ml}$ of PBS containing $25 \mathrm{mM}$ glucose, $100 \mu \mathrm{g}$ of lactoperoxidase ( $8 \mathrm{U}$, Sigma Chemical Co.), $50 \mu \mathrm{g}$ of glucose oxidase (10 U, Calbiochem-Behring Corp., San Diego, CA) and $500 \mu \mathrm{Ci}$ of ${ }^{125} \mathrm{I}-\mathrm{Na}$ (13-17 mCi $/ \mu \mathrm{g} \mathrm{I}$, Amersham Corp.) for $45 \mathrm{~min}$ at $4^{\circ} \mathrm{C}$. Cells were then washed three times in $2 \mathrm{ml}$ of ice-cold PBS, and a final wash was performed with $2 \mathrm{ml}$ of ice-cold PBS containing $\mathrm{KI}(1 \mu \mathrm{g} / \mathrm{ml})$.

Immunoprecipitation. Surface-labeled cells were lysed in $1 \mathrm{ml}$ of buffer containing $0.1 \%$ rat serum albumin, $1 \%$ Nonidet P40, $1 \mathrm{mM}$ EGTA, $10 \mathrm{mM}$ Tris, pH 7.6, $2 \mathrm{mM}$ phenylmethylsulfonyl fluoride (PMSF), and $150 \mathrm{mM} \mathrm{NaCl}$. Cell lysates were centrifuged for $2 \mathrm{~min}$ in an Eppendorf centrifuge (model 5414, Brinkmann Instruments Co., Westbury, NY) and the resulting supernatant was incubated for 30 min at $4^{\circ} \mathrm{C}$ with constant mixing with $50 \mu \mathrm{l}$ of $20 \%$ Protein A-Sepha- rose (Sigma Chemical Co.) suspended in PBS. Beads were removed by centrifugation, the supernatant was incubated with $10 \mu \mathrm{l}$ of nonimmune rabbit serum for $30 \mathrm{~min}$ at $4^{\circ} \mathrm{C}$, and $50 \mu \mathrm{l}$ of $20 \%$ Protein A-Sepharose was added for $30 \mathrm{~min}$ at $4^{\circ} \mathrm{C}$. After centrifugation for 2 min at $4^{\circ} \mathrm{C}$, the supernatant was incubated with anti-OABP or antifusion protein serum $(10 \mu \mathrm{l})$ for $3 \mathrm{~h}$ at $4^{\circ} \mathrm{C}$. Antigen-antibody complexes were recovered by adsorption to $50 \mu \mathrm{l}$ of $20 \%$ Protein A-Sepharose for $30 \mathrm{~min}$ at $4^{\circ} \mathrm{C}$ followed by centrifugation for $2 \mathrm{~min}$. Protein A-Sepharose beads were then washed five times with $1 \mathrm{ml}$ of $10 \mathrm{mM}$ Tris, pH 7.2, $150 \mathrm{mM} \mathrm{NaCl}, 1 \%$ Triton X-100, $1 \%$ sodium deoxycholate, and $0.1 \%$ SDS (13) and once with $0.05 \mathrm{M}$ Tris-saline, $\mathrm{pH}$ 7.4. The antigen-antibody complexes were removed from the Protein A-Sepharose beads and denatured by boiling in SDS-PAGE sample buffer containing $5 \% \beta$-mercaptoethanol for $3 \mathrm{~min}$. The protein A-Sepharose beads were removed by centrifugation and the supernatant was subjected to $10 \%$ SDS-PAGE. Fixed gels were dried and subjected to radioautography (13).

Photoaffinity labeling of $F_{1}$-ATPase with $\left[{ }^{35} S\right] B S P .\left[{ }^{35} \mathrm{~S}\right] \mathrm{BSP}$ at a specific activity of $3,400 \mathrm{mCi} / \mathrm{mmol}$ was prepared by sulfonation of phenoltetrabromophthalein with $\mathrm{H}_{2}{ }^{35} \mathrm{SO}_{4}(14)$. Purified bovine $\mathrm{F}_{1}$ ATPase was a gift from Dr. Harvey Penefsky, SUNY Health Science Center, Syracuse, NY). Approximately $23 \mu \mathrm{g}$ of protein was photoaffinity-labeled with 22 pmol of ${ }^{35}$ S]BSP in $100 \mu$ l of PBS, pH 7.4, as previously described (7). An aliquot of this mixture was subjected to SDS-PAGE and fluorography.

Preparation of liver tissue for immunocytochemistry. Male Sprague-Dawley rats (250-300 g) (Marland Farms, Hewitt, NJ) were anesthetized by ether, and the livers were fixed either by perfusion or immersion at $4^{\circ} \mathrm{C}$ with $4 \%$ paraformaldehyde in $0.1 \mathrm{M}$ phosphate buffer, $\mathrm{pH} 7.4,7.5 \%$ sucrose for a total of $4 \mathrm{~h}$ (15). After an overnight rinse in cold $0.1 \mathrm{M}$ phosphate buffer, $\mathrm{pH} 7.4,7.5 \%$ sucrose, nonfrozen sections $\sim 30 \mu \mathrm{m}$ thick were prepared with an Oxford Vibratome (Ted Pella, Tustin, CA), using a slow speed and high amplitude setting, and placed in cold $7.5 \%$ sucrose. Sections were exposed to rabbit antiOABP serum at $4^{\circ} \mathrm{C}$ for $20-40 \mathrm{~h}$, with intermittent, mild agitation. Single sections $\left(\sim 2 \mathrm{~mm}^{2}\right)$ were placed in tissue culture U-shaped multiwell plastic trays (Linbro, Flow Laboratories, Inc., McLean, VA) that contained $0.2 \mathrm{ml}$ of antiserum diluted 1:100 with PBS containing 1\% BSA. After several rinses in cold PBS, the sections were treated with Protein A-horseradish peroxidase $(0.1 \mathrm{ml} / \mathrm{ml})$ (E. Y. Laboratories, San Mateo, CA) for $1 \mathrm{~h}$ at room temperature in the dark. After several rinses in PBS and in $7.5 \%$ sucrose, the sections were incubated in 3,3'-diaminobenzidine tetrahydrochloride (Sigma Chemical Co.) at pH $7.6(15)$ at room temperature for $10 \mathrm{~min}$ in the dark to reveal peroxidase activity, and examined by light microscopy. Some sections were processed for electron microscopy as previously described (15).

Immunogold localization studies. Immunogold-labeling was performed on LR-White (London Resin, Ltd., Hampshire, England) ultrathin sections. Fixation was done by vascular perfusion with $2 \%$ paraformaldehyde plus $0.1 \%$ glutaraldehyde in PBS (pH 7.4) for $5 \mathrm{~min}$, followed by immersing dissected cubes of liver in PBS at $4^{\circ} \mathrm{C}$ for $12 \mathrm{~h}$. The tissue was then rinsed in PBS at $4^{\circ} \mathrm{C}$ overnight, dehydrated in a graded series of ethanol concentrations, and immersed in $100 \%$ LRWhite; the samples were encapsulated in resin and polymerized by irradiation using a black light source (UV light, $282 \mathrm{~nm}$ ) at $4^{\circ} \mathrm{C}$. Suitable consistency of the blocks was obtained after 3-4 d of polymerization. Ultrathin sections were cut by means of an Ultratome (Reichert Scientific Instruments, Buffalo, NY), mounted on Formavar/Carboncoated $\mathrm{Cu}$ grids, and further processed for immunolabeling. Labeling with the primary antibody was achieved by using a $10-\mu 1$ droplet of polyclonal anti-OABP (1:50). Affinity-purified goat anti-rabbit IgG coupled to colloidal gold (5-6 nm, Janssen Pharmaceutica, Beerse, Belgium) was used as a second marker.

\section{Results}

Identification of $O A B P$-reactive clones from a $\lambda$ gt 11 rat liver expression library. Approximately $2 \times 10^{6}$ plaques produced 
from a $\lambda g t 11$ cDNA rat liver library were screened with goat anti-rat OABP antibody, and six positive plaques were identified. These plaques were purified by three additional cycles of plating and screening with the same antibody. DNA was purified from these phage, digested with $E c o R I$, and subjected to agarose gel electrophoresis. The DNA patterns from the six recombinant DNAs were identical, consisting of two bands of $\sim 1,250$ and 300 base pairs, indicating the presence of an internal EcoRI site. The two EcoRI insert DNA fragments from one clone were subcloned into pGEM 2 .

Immunologic characterization of the recombinant protein in $E$. coli. Lysogenic $E$. coli were induced with isopropyl $\beta$-Dthiogalactopyranoside to produce the $\beta$-galactosidase-OABP fusion protein. This recombinant protein was virtually insoluble in detergent at $4^{\circ} \mathrm{C}$, and was purified by preparative $7.5 \%$ SDS-PAGE after extraction of the lysate sequentially with $1 \%$ Triton X-100 and $1 \%$ deoxycholate (Fig. 1, left). Immunoblot analysis of the $E$. coli lysate revealed the presence of an $\sim 160-\mathrm{kD}$ band reacting with both antibody to $\beta$-galactosidase and antibody to OABP (Fig. 1, right). Nontransformed $E$. coli lacked this immunoreactivity (Fig. 1, right).

Immunoblot analysis using antibody to the purified recom-



Figure 1. (Left) Expression of recombinant protein in E. coli. E. coli strain Y1089 was transfected with $\lambda \mathrm{gt} 11$ phage coding for immunoactive OABP, and expression of the protein as a hybrid with bacterial $\beta$-galactosidase was induced as described in Methods. This recombinant protein was virtually insoluble in detergent at $4^{\circ} \mathrm{C}$, and was purified by preparative $7.5 \%$ SDS-PAGE after extraction of the bacterial lysate sequentially with $1 \%$ Triton X-100 and $1 \%$ deoxycholate. Lane $A$, Coomassie-stained SDS-PAGE of the bacterial lysate. Lane $B$, Coomassie-stained SDS-PAGE of the purified fusion protein. This preparation was used to immunize rabbits. (Right) Immunoblot analysis of the recombinant protein. $E$. coli lysate was subjected to $10 \%$ SDS-PAGE, transferred to nitrocellulose, and probed with either antibody to $E$. coli $\beta$-galactosidase (lane $A$ ) or anti-OABP (lane $C$ ). Lane $B$ represents a lysate from nontransformed $E$. coli probed with anti-OABP. These results indicate a single protein with immunoreactivity to $\beta$-galactosidase and OABP. The lower band in lane $\boldsymbol{A}$ presumably represents synthesis of an incomplete $\beta$-galactosidase protein. Molecular mass markers at left in both panels are in kilodaltons.

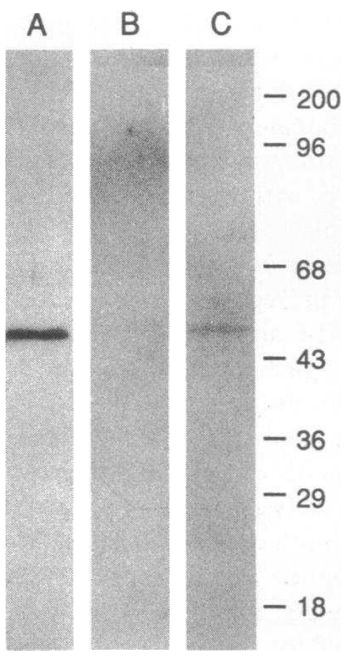

Figure 2. Immunologic identity of $\mathrm{OABP}$ and the recombinant protein. Three immunoblots performed against purified OABP are shown. Lane $A$, reaction of anti-fusion protein antibody with purified rat OABP. Lanes $B$ and $C$, antibody reactivity was markedly reduced after preabsorption with OABP (lane $B$ ) or fusion protein (lane $C$ ). Similar results were obtained with the original antiOABP antibody. Molecular mass markers at right are in kilodaltons.

binant fusion protein revealed a similarly sized $55-\mathrm{kD}$ band with purified OABP (Fig. 2) and rat liver homogenate (data not shown). This immunoreactivity was markedly reduced after preabsorption of the antibody with either OABP or the fusion protein (Fig. 2). Similar results were obtained with the original anti-OABP antibody (data not shown).

Nucleotide sequence and deduced amino acid sequence of $O A B P$ CDNA. A partial restriction map of the 1500-base pair $\lambda$ gt 11 cDNA insert is shown in Fig. 3. The five DNA fragments labeled $a-e$ were subcloned into either pGEM-2 $(b, e)$, pGEM-3Z $(c, d)$, or pGEM-3 $(a)$. In addition the two EcoRI restriction fragments were subcloned into pGEM-2. These subclones were sequenced using the strategy shown in Fig. 3. Computer analysis of the DNA sequence revealed identity with bases 63-1558 of the published sequence of the $\beta$-subunit of rat mitochondrial $F_{1}$-ATPase (16).

Immunological identity of $O A B P$ and the $\beta$-subunit of mitochondrial $F_{1}$-ATPase. Rabbit antibody raised against the $\beta$ subunit of yeast $F_{1}-A T P a s e$ provided by Dr. Michael Douglas (University of Texas, Dallas) was used for immunoblot analy-

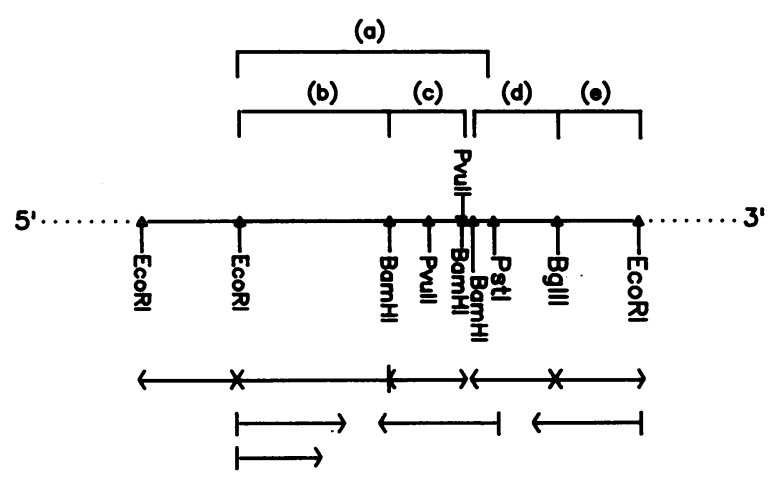

$0.5 \mathrm{~kb}$

Figure 3. Restriction map and sequencing strategy of OABP cDNA. The five fragments labeled $a-e$ were subcloned and inserted into either pGEM-2 $(b, e)$, pGEM-3Z $(c, d)$, or pGEM-3 $(a)$. In addition, the two EcoRI restriction fragments were subcloned into pGEM-2. These subclones were sequenced and used to deduce the nucleotide sequence of the original cDNA using the strategy indicated by the arrows. The direction of the arrowheads indicates the direction in which the fragments were sequenced. 
sis of rat liver OABP, bovine heart $F_{1}$-ATPase, and rat liver homogenate. A single immunoreactive protein band was detected (Fig. 4). Identical results were obtained when anti-rat liver OABP antibody was used (data not shown).

Northern blot analysis. As seen in Fig. 5, a single mRNA of $\sim 1.7 \mathrm{~kb}$ hybridized with the 1,250 -base pair $\left[{ }^{32} \mathrm{P}\right] \mathrm{cDNA}$.

Immunoprecipitation with surface iodinated rat hepatocytes. The cell surface proteins of overnight cultures of rat hepatocytes were selectively radiolabeled with ${ }^{125} \mathrm{I}$ using soluble lactoperoxidase/glucose oxidase at $4^{\circ} \mathrm{C}$ for $45 \mathrm{~min}$. A major band on SDS-PAGE migrating at $55 \mathrm{kD}$ (Fig. 6) was immunoprecipitated with antibody against the recombinant protein. This band was not seen after immunoprecipitation with nonimmune serum or with antibody that had been preabsorbed with recombinant protein (Fig. 6).

Immunocytochemistry studies. To directly visualize antigenic localization, sections of rat liver were examined using immunocytochemistry. Bound antibody was detected by immunoperoxidase staining. As seen in Fig. 7, by light microscopy, anti-OABP antibody reacted with the sinusoidal and basolateral cell surface but not with the canalicular membrane. Diffuse granular cytoplasmic staining, compatible with a mitochondrial subcellular localization, was also seen. Immunoreactivity was not seen with nonimmune serum or with antiOABP that had been preabsorbed with the recombinant protein. By electron microscopy, reaction product was clearly seen on sinusoidal and basolateral but not canalicular surfaces of hepatocytes (Fig. 8). Visualization of immunoreactivity in mitochondria was difficult. However, using immunogold methodology, antigen was clearly detected within mitochondria (Fig. 9).

Photoaffinity labeling of $F_{1}$-ATPase with $\left[{ }^{35} S\right] B S P$. Bovine cardiac $F_{1}$-ATPase was photoaffinity-labeled with high-specific-activity $\left[{ }^{35} \mathrm{~S}\right] \mathrm{BSP}$. The labeled material was then subjected to $15 \%$ SDS-PAGE and fluorography. These studies revealed that $\left[{ }^{35}\right.$ S]BSP bound only to the $\beta$-subunit (Fig. 10).

\section{Discussion}

In previous studies, we found high-affinity binding of $\left[{ }^{35} \mathrm{~S}\right] \mathrm{BSP}$ to a sinusoidal surface-derived rat liver cell plasma membrane subfraction (7). Binding was eliminated by preincubation of membrane with trypsin. Photoaffinity labeling of this membrane subfraction with $\left[{ }^{35} \mathrm{~S}\right] \mathrm{BSP}$ revealed a predominant 55-kD protein, and this was purified to high degree by BSPSepharose affinity chromatography (7). Antibody raised to this OABP reacted with the surface of short-term cultured rat hepatocytes as determined by immunofluorescence (8).

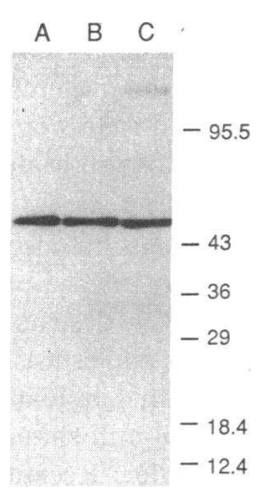

Figure 4. Immunologic cross-reactivity of $\mathrm{OABP}$ and the mitochondrial $\mathrm{F}_{1}-\mathrm{ATPase} \beta$ subunit. Antibody to the $\beta$-subunit of yeast $\mathrm{F}_{1}$-ATPase was provided by Dr. Michael Douglas. It was used to probe by immunoblot OABP (lane $A$ ), bovine $\mathrm{F}_{1}$-ATPase (provided by Dr. Harvey Panefsky, lane $B$ ), and rat liver homogenate (lane $C$ ). A single band is seen in all three lanes, indicating cross-reactivity between the $\beta$-subunit of mitochondrial $F_{1}-A T P a s e$ and OABP.



Figure 5. Northern blot analysis of OABP cDNA. Rat liver total (lane $A$ ), poly $\mathrm{A}(-)$ (lane $B$ ), and poly $\mathrm{A}(+)$ (lane $C$ ) mRNA was electrophoresed on $1 \%$ agarose and transferred to Gene Screen. Northern blot analysis was performed after ${ }^{32} \mathrm{P}$ labeling of the 1,250-base pair cDNA insert by primer extension using $\left[{ }^{32} \mathrm{P}\right] \mathrm{dCTP}$. Hybridization was overnight in $50 \%$ formamide, $5 \times$ SSC, and $2 \times$ Denhardt's solution. The blot was washed twice at $65^{\circ} \mathrm{C}$ with $0.1 \%$ SDS in $0.1 \times$ SSC. A single, $\sim 1.7-\mathrm{kb}$ poly $\mathrm{A}(+)$ mRNA hybridized with this probe.

Two other candidate organic anion transport proteins have been identified $(17,18)$. Their relationship to OABP is not clear. Antibody to the protein isolated by Stremmel and Berk (17) partially inhibited BSP uptake by isolated hepatocytes. However, large amounts of antibody were necessary, and uptake was determined only at high concentrations of BSP in the absence of albumin. It is questionable whether a physiologic, or a higher capacity, lower affinity organic anion transporter was studied $(5,6)$. Sottocasa et al. (18) reconstituted BSP uptake in liposomes with their candidate transporter. The relationship of this protein to the other organic anion binding proteins and to physiologic organic anion transport is yet to be established. Ultimate determination of function of these proteins may await transfection of transport-deficient cells with specific full-length cDNAs.

In the present study, the antibody to purified OABP was used to clone a cDNA from a rat liver expression library. This cDNA coded for $\sim 80 \%$ of the apparent molecular weight of mature OABP and was expressed in $E$. coli as a fusion protein with $\beta$-galactosidase. Antibody raised to the fusion protein or antibody to native OABP reacted with both proteins as indicated by loss of antibody activity after absorption against either protein. This immunologic cross-reactivity indicates a high degree of homology between the affinity purified OABP and the fusion protein encoded by the cDNA. Cómputer analysis of the cDNA sequence revealed identity with the published cDNA sequence for the $\beta$-subunit of rat mitochondrial $F_{1}$-ATPase (16). This $F_{1}$-ATPase subunit and OABP were of the same molecular mass as estimated by SDS-PAGE and were immunologically cross-reactive (Fig. 4).



Figure 6. Immunoprecipitation of ${ }^{125}$ I surfacelabeled rat hepatocytes. Surface proteins of overnight cultures of rat hepatocytes were radiolabeled with ${ }^{125} \mathrm{I}$ using soluble lactoperoxidase/glucose oxidase at $4^{\circ} \mathrm{C}$ for $45 \mathrm{~min}$. The cell lysate was subjected to immunoprecipitation, and SDS gel electrophoresis was performed. Immunoprecipitation with anti-fusion protein antibody revealed a major $55-\mathrm{kD}$ band. No band was seen after immunoprecipitation with antibody that was preabsorbed with fusion protein (lane $B$ ) or with preimmune serum (lane $C$ ). Molecular mass markers at right are in kilodaltons. 


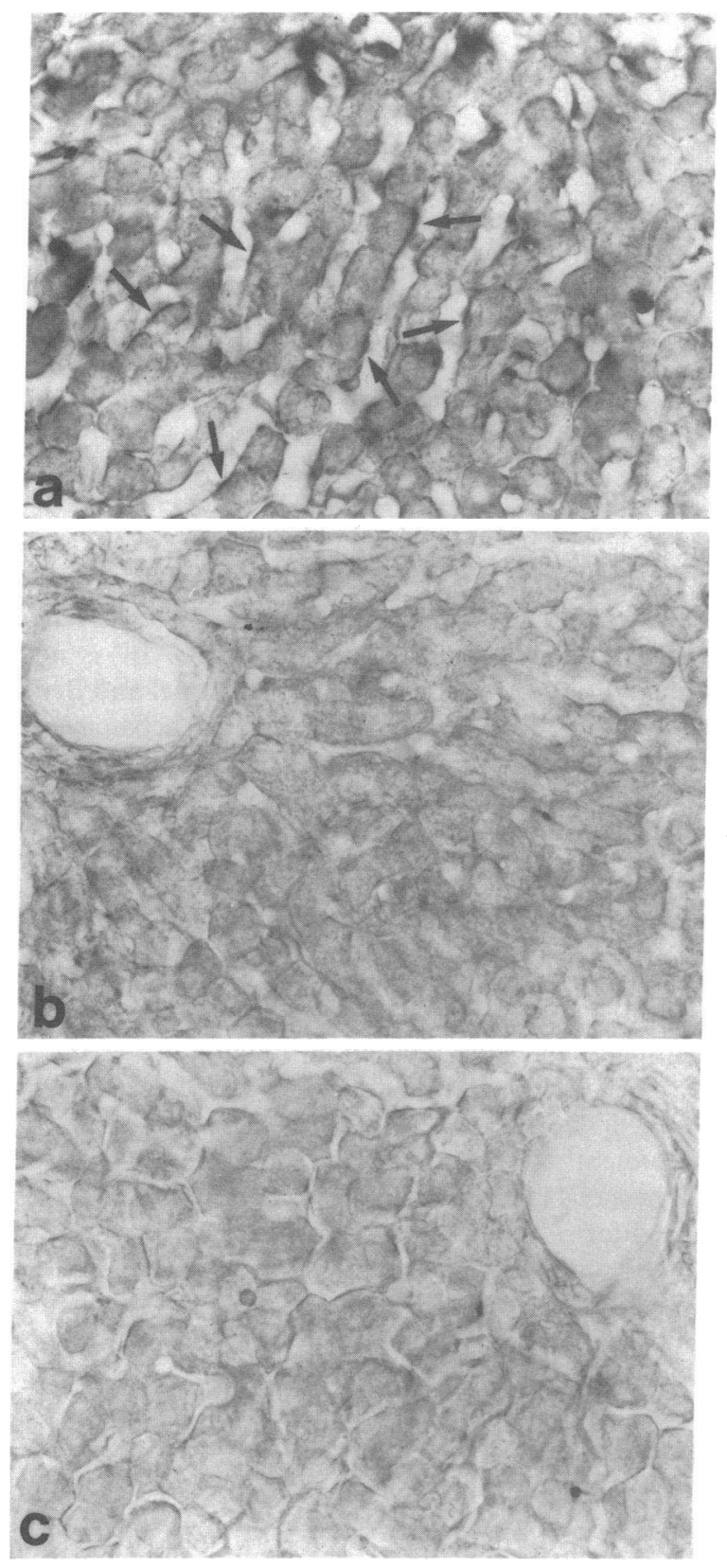

Figure 7. Hepatocyte surface localization of OABP after absorption of antibody with recombinant protein. (a) A section of aldehydefixed rat liver was exposed to anti-OABP antisera diluted 1:100, treated with Protein A-peroxidase, and incubated in diaminobenzidine at $\mathrm{pH} 7.6$ to reveal sites of peroxidase activity. OABP antigen was localized only in hepatocytes and their basolateral plasma membrane domains. The apical plasma membrane domains (bile canaliculi) did not demonstrate the antigen. Punctate intracellular reaction product, consistent with mitochondrial localization, was also seen. Arrows indicate the portion of the OABP-positive membrane facing the sinusoids. $\times 400$. (b) Section exposed to anti-OABP antisera absorbed against fusion protein and processed as in $a$. Essentially little or no OABP antigen localization is evident in hepatocyte basolateral plasma membrane. $\times 400$. (c) Section exposed to nonimmune serum and processed as in $a$. This control section shows no staining at the hepatocyte basolateral surfaces. $\times 400$.

Although the presence of OABP in sinusoidal rat liver cell subfractions could be due to a small amount of mitochondrial contamination, several lines of evidence suggest both a liver cell surface and inner mitochondrial localization of this antigen. By ELISA, OABP was 14-fold enriched in sinusoidal subfractions in which mitochondrial enzyme markers were deenriched (8). Surface iodination of cultured hepatocytes at $4^{\circ} \mathrm{C}$ and immunoprecipitation using anti-OABP (Fig. 6) resulted in specific recovery of a $55-\mathrm{kD}$ protein (Fig. 6). These results suggesting hepatocyte surface localization of OABP were confirmed by immunocytochemistry at both the lightand electron-microscopic level. In rat liver, surface localization of OABP is seen only in hepatocytes. The widespread tissue homogenate distribution of the antigen reported previously (8), probably derives from its presence in mitochondria.

The $\beta$-subunit of $F_{1}$-ATPase, an inner mitochondrial membrane protein, has not been previously described on the plasma membrane. The $\beta$-subunit precursor is coded from chromosomal DNA which is thought to be translated on free polysomes (19). The signal for mitochondrial localization of this protein resides at the $\mathrm{NH}_{2}$ terminus (20). After binding, the precursor protein is translocated into mitochondria by an ATP-dependent process during which the $\mathrm{NH}_{2}$-terminal $\sim 60$ amino acids are cleaved, producing the mature form of the protein (20-22). These events differ from those characterizing the usual synthetic pathway for plasma membrane proteins, involving signal recognition protein-dependent synthesis on membrane-bound polysomes (23-25). However, since the liver cell mitochondrial membrane area is $\sim 25$ times that of the plasma membrane (26), it is possible that a small yet significant percent of mRNA coding for the $\beta$-subunit of $F_{1}$-ATPase is translated via the signal recognition protein-dependent translocation mechanism. Alternatively, there may be heterogeneity in mRNA coding for the signal sequence of this protein at the $5^{\prime}$ translated region. Such heterogeneity could arise from a mechanism such as tissue-specific alternate splicing of RNA, or alternative start sites. These possibilities will be the subject of future studies. Although Northern blot analysis revealed a single band upon hybridization of rat liver mRNA with our cDNA, microheterogeneity within this band must be considered. Both the cDNA obtained by us and the cDNA obtained by Garboczi et al. (16) lack the $\mathrm{NH}_{2}$-terminal 200-250 nucleotides as judged by comparison with the sequence of the human $F_{1}$-ATPase $\beta$-subunit (27).

The presence of identical or closely related proteins in mitochondria and plasma membrane has been suggested in other systems. Berk et al. (28) reported that a rat hepatic plasma membrane, fatty acid binding protein and mitochondrial glutamate-oxaloacetate transaminase located in the mitochondrial matrix, share a number of properties. They found that the sequence of the $24 \mathrm{NH}_{2}$-terminal amino acids of the fatty acid binding protein are identical to the published sequence for mitochondrial glutamate-oxaloacetate transaminase. Monospecific polyclonal antisera raised against each of the proteins cross-reacted with the other protein. Each of the antisera were reported to exhibit "cytoplasmic" (presumably mitochondrial) and plasma membrane immunofluorescence staining.

Cell surface localization of mitochondrial antigens has also been observed in primary biliary cirrhosis, a liver disease of unknown etiology characterized by slowly progressive destruction of biliary epithelium and signs of increasing cholestasis, resulting eventually in profound jaundice and death. Circulating antibodies that react with mitochondria (anti-mitochondrial antibodies) are characteristic of this disorder. Recent 



Figure 8. Electron-microscopic immunocytochemical localization of OABP in nonfrozen sections of aldehyde-fixed rat liver. (Top) Reaction product is present at both the sinusoidal $(S P)$ and lateral $(L P)$ hepatocyte plasma membrane but is absent from the bile canaliculus $(B C)$.

$\times 44,000$. (Bottom) Reaction product is present only in the lateral plasma membrane $(L P)$. No reaction product is detected in the bile canaliculus $(B C) . \times 42,000$.

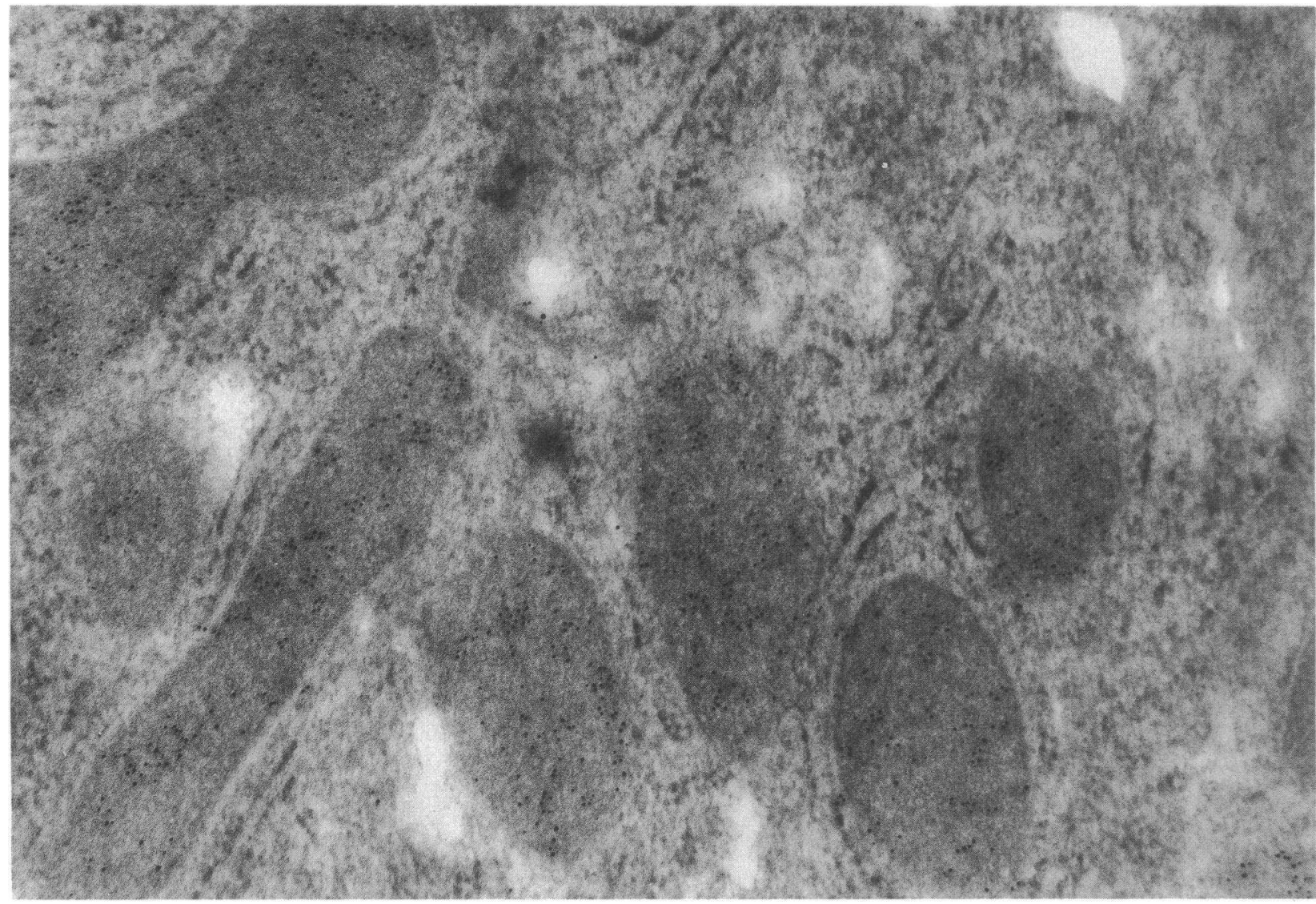

Figure 9. Immunogold localization of OABP in rat liver mitochondria. Ultramicrotome sections of LR-White ultrathin sections of $2 \%$ paraformaldehyde $/ 0.1 \%$ glutaraldehyde-fixed rat liver were prepared as described in Methods and localization of anti-OABP was identified after incubation in goat anti-rabbit IgG coupled to colloidal gold (5-6 nm). Abundant gold particles are seen within mitochondria $(\times 100,000)$. 


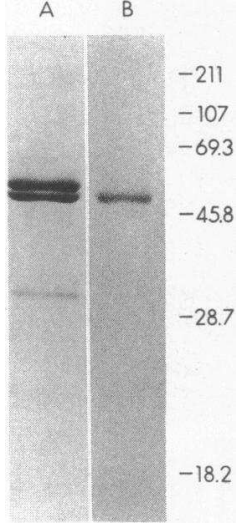

Figure 10. $\left[{ }^{35} \mathrm{~S}\right] \mathrm{BSP}$ photoaffinity labeling of bovine $F_{1}$-ATPase. Approximately $23 \mu \mathrm{g}$ of protein was photoaffinity-labeled with 22 pmol of $\left.{ }^{35} \mathrm{~S}\right] \mathrm{BSP}(3,400 \mathrm{mCi} / \mathrm{mmol})$ as described in Methods. SDS-PAGE on a $15 \%$ polyacrylamide gel was performed and stained with Coomassie blue (lane $A$ ). Bands corresponding to the $\alpha$-(upper), $\beta$-(middle), and $\gamma$ subunits (lower) are seen. Fluorography of this gel was then performed and revealed localization of radioactivity only in the $\beta$-subunit (lane $B$ ).

studies suggest that the primary biliary cirrhosis specific antigen(s) are in plasma membrane as well as mitochondrial subcellular fractions (29). These studies also demonstrated by immunofluorescence reactivity of these sera with a hepatoma cell surface antigen(s); immunofluorescence was eliminated by preabsorption of antisera with bovine heart mitochondria (29).

The functional significance of these findings is not as yet known. Previous studies that we performed in cultured rat hepatocytes revealed that uptake of bilirubin and BSP required cellular ATP and the presence of $\mathrm{Cl}^{-}(6)$. Other studies revealed that mitochondria transport organic anions such as BSP $(30,31)$, and in high doses, BSP and bilirubin inhibit mitochondrial respiration (32). The $\left[{ }^{35} \mathrm{~S}\right] \mathrm{BSP}$ photoaffinity-labeling studies, which were performed in an approximately threefold molar excess of native bovine $F_{1}$-ATPase using the molecular mass of 371,135 daltons as determined by Walker et al. (33), indicate that only the $\beta$-subunit bound BSP (Fig. 10). The presence of an organic anion binding site on the $F_{1}$-ATPase $\beta$-subunit suggests that it may play a role in these processes.

\section{Acknowledgments}

We acknowledge the assistance of Dr. Rui Liu in performing the Northern blot analysis.

This work was supported by National Institutes of Health grants DK-23026 (Dr. Wolkoff), CA-06576 (Dr. Novikoff), DK-32972 (Dr. Stockert), CA-45476 (Dr. Burk), and DK-41296 (Liver Research Center). Dr. Burk is also supported by a grant from the American Cancer Society (JFRA-172) and the Sinsheimer Foundation. Computer resources used to carry out our studies were provided by the BIONET National Computer Resource for Molecular Biology which is funded by the Biomedical Research Technology Program, Division of Research Resources, National Institutes of Health, grant P41RR01685.

\section{References}

1. Scharschmidt, B. F., J. G. Waggoner, and P. D. Berk. 1975. Hepatic organic anion uptake in the rat. J. Clin. Invest. 56:1280-1292.

2. Stollman, Y. R., U. Gartner, L. Theilmann, N. Ohmi, and A. W. Wolkoff. 1983. Hepatic bilirubin uptake in the isolated perfused rat liver is not facilitated by albumin binding. J. Clin. Invest. 72:718-723.

3. Wolkoff, A. W. 1987. The role of an albumin receptor in hepatic organic anion uptake: the controversy continues. Hepatology. 7:777779.

4. Goresky, C. A. 1964. Initial distribution and rate of uptake of sulfobromophthalein in the liver. Am. J. Physiol. 207:13-26.
5. Lan, J. A., L. R. Chervu, K. L. Johansen, and A. W. Wolkoff. 1988. Uptake of technetium $99 \mathrm{~m}$ hepatobiliary imaging agents by cultured rat hepatocytes. Gastroenterology. 95:1625-1631.

6. Wolkoff, A. W., A. C. Samuelson, K. L. Johansen, R. Nakata, D. M. Withers, and A. Sosiak. 1987. Influence of $\mathrm{Cl}^{-}$on organic anion transport in short-term cultured rat hepatocytes and isolated perfused rat liver. J. Clin. Invest. 79:1259-1268.

7. Wolkoff, A. W., and C. T. Chung. 1980. Identification, purification, and partial characterization of an organic anion binding protein from rat liver cell plasma membrane. J. Clin. Invest. 65:1152-1161.

8. Wolkoff, A. W., A. Sosiak, H. C. Greenblatt, J. Van Renswoude, and R. J. Stockert. 1985. Immunological studies of an organic anionbinding protein isolated from rat liver cell plasma membrane. J. Clin. Invest. 76:454-459.

9. Young, R. A., and R. W. Davis. 1983. Yeast RNA polymerase II genes: isolation with antibody probe. Science (Wash. DC). 222:778782.

10. Hunkapillar, M. W., E. Lujan, F. Ostrander, and L. E. Hood. 1983. Isolation of microgram quantities of proteins from polyacrylamide gels for amino acid sequence analysis. Methods Enzymol. 91:227-236.

11. Czaja, M. J., F. R. Weiner, M. Eghbali, M-A., Giambrone, M. Eghbali, and M. A. Zern. 1987. Differential effects of $\gamma$-interferon on collagen and fibronectin gene expression. J. Biol. Chem. 262:13348 13351.

12. Wolkoff, A. W., R. D. Klausner, G. Ashwell, and J. Harford. 1984. Intracellular segregation of asialoglycoproteins and their receptor: a prelysosomal event subsequent to dissociation of the ligand-receptor complex. J. Cell Biol. 98:375-381.

13. Paietta, E., R. J. Stockert, A. G. Morell, V. Diehl, and P. H. Wiernik. 1986. Unique antigen of cultured Hodgkin's cells. J. Clin. Invest. 78:349-354.

14. Kurisu, H., P. Nilprabbhasorn, and A. W. Wolkoff. 1989. Preparation of ${ }^{35} \mathrm{~S}$-sulfobromophthalein of high specific activity. Anal. Biochem. 179:72-74.

15. Novikoff, P. M., N. F., LaRusso, A. B. Novikoff, R. J. Stockert, A. Yam, and G. D. LeSage. 1983. Immunocytochemical localization of lysosomal $\beta$-galactosidase in rat liver. J. Cell Biol. 97:1559-1565.

16. Garboczi, D. N., A. H. Fox, S. L. Gerring, and P. L. Pedersen. 1988. $\beta$-subunit of rat liver mitochondrial ATP synthase: cDNA cloning, amino acid sequence, expression in Escherichia coli, and structural relationship to adenylate kinase. Biochemistry. 27:553-560.

17. Stremmel, W., and P. D. Berk. 1986. Hepatocellular uptake of sulfobromophthalein and bilirubin is selectively inhibited by an antibody to the liver plasma membrane sulfobromophthalein/bilirubin binding protein. J. Clin. Invest. 78:822-826.

18. Sottocasa, G. L., G. Baldini, G. Sandri, G. Lunazzi, and C. Tiribelli. 1982. Reconstitution in vitro of sulfobromophthalein transport by bilitranslocase. Biochim. Biophys. Acta. 685:123-128.

19. Mihara, K., T. Omura, T. Harano, S. Brenner, S. Fleischer, K. V. Rajagopalan, and G. Blobel. 1982. Rat liver L-glutamate dehydrogenase, malate dehydrogenase, $D$ - $\beta$-hydroxybutyrate dehydrogenase, and sulfite oxidase are each synthesized as larger precursors by cytoplasmic free polysomes. J. Biol. Chem. 257:3355-3358.

20. Douglas, M. G., M. T. McCammon, and A. Vassarotti. 1986. Targeting proteins into mitochondria. Microbiol. Rev. 50:166-178.

21. Hay, R., P. Böhni, and S. Gasser. 1984. How mitochondria import proteins. Biochim. Biophys. Acta. 779:65-87.

22. Schatz, G., R. A. and Butow. 1983. How are proteins imported into mitochondria? Cell. 32:316-318.

23. Walter, P., and G. Blobel. 1981. Translocation of proteins across the endoplasmic reticulum. III. Signal recognition protein (SRP) causes signal sequence-dependent and site-specific arrest of chain elongation that is released by microsomal membranes. $J$. Cell Biol. 91:557-561.

24. Walter, P., and G. Blobel. 1981. Translocation of proteins across the endoplasmic reticulum. II. Signal recognition protein (SRP) mediates the selective binding to microsomal membranes of in vitro- 
assembled polysomes synthesizing secretory proteins. J. Cell Biol. 91:551-556.

25. Walter, P., I. Ibrahimi, and G. Blobel. 1981. Translocation of proteins across the endoplasmic reticulum. I. Signal recognition protein (SRP) binds to in vitro-assembled polysomes synthesizing secretory proteins. J. Cell Biol. 91:545-550.

26. Weibel, E. R., W. Stäubli, H. R. Gnägi, and F. A. Hess. 1969. Correlated morphometric and biochemical studies on the liver cell. I. Morphometric model, stereologic methods, and normal morphometric data for rat liver. J. Cell Biol. 42:68-91.

27. Ohta, S., and Y. Kagawa. 1986. Human $F_{1}$-ATPase: molecular cloning of cDNA for the beta subunit. J. Biochem. 99:135-141.

28. Berk, P. D., B. J. Potter, D. Sorrentino, W. Stremmel, D Stump, C.-L. Kiang, and S.-L. Zhou. 1989. Characteristics of organic anion binding proteins from rat liver sinusoidal plasma membranes. In Hepatic Transport of Organic Substances. E. Petzinger, R. K. H Kinne, and H. Sies, editors. Springer-Verlag, Berlin. 195-210.

29. Ghadiminejad, I., and H. Baum. 1987. Evidence for the cell- surface localization of antigens cross reacting with the "mitochondria antibodies" of primary biliary cirrhosis. Hepatology. 7:743-749.

30. Burr, R., M. Schwenk, and E. Pfaff. 1977. Interaction of bromosulfophthalein with mitochondrial membranes: uptake of bromosulfophthalein and effect on ANS-fluoresence. Biochem. Pharmacol. 26:457-460.

31. Laperche, Y., and P. Oudea. 1976. Inhibition by sulfobromophthalein of mitochondrial translocation of anions and adenine nucleotides: effects upon liver adenosine triphosphate and possible correlation with inhibition of bile flow in the rat. J. Pharmacol. Exp. Ther. 197:235-244.

32. Burr, R., M. Schwenk, and E. Pfaff. 1977. Interaction of bromosulfophthalein with mitochondrial membranes: inhibition of respiration. Biochem. Pharmacol. 26:461-466.

33. Walker, J. E., I. M. Fearnley, N. J. Gay, B. W. Gibson, F. D. Northrop, S. J. Powell, M. J. Runswick, M. Saraste, and V. L. J. Tybulewicz. 1985. Primary structure and subunit stoichiometry of $\mathrm{F}_{1}$-ATPase from bovine mitochondria. J. Mol. Biol. 184:677-701. 